Committee, Chief, Department of Dermatology, Gifu National University, Medical College, Gifu, Japan.

\section{Transplanted Tumours}

The Imperial Cancer Research Fund has just issued the ninth volume of its bibliography on research using transplanted tumours of laboratory animals. The subject index of some hundred pages is an alphabetical cross-referenced list of contents; it is followed by the tumour index, subdivided by animal; bibliography and suthor index occupy the next hundred pages; and the booklet ends with a list of 91 journalsall in English-from which the information has been extracted. Research Using Transplanted: Tumours of Laboratory Animals: A Cross-Referenced Bibliography-IX 1972 by D. C. Roberts and M. Barton is available free on application to Dr. D. C Roberts, Research Data Unit, Imperial Cancer Research Fund, Burtonhole Lane, London N.W.7. Requests for the next volume in the series should be sent to the same address.

\section{Counselling Homosexuals}

A study of personal needs of homosexuals and public attitudes towards them has been compiled by Peter Righton, based on inquiries made by a working party of the National Council of Social Service. After describing the nature of the problems there are sections dealing with their solution, which include counselling by those instructed to do so and the kind of help needed to cope wth the most serious aspect-social isolation. The 35-page booklet Counselling Homosexuals, Bedford Square Press of the National Council of Social Service, is available from 26 Bedford Square, London, W.C.1. Price 30p.; by post 35p.

\section{Order of St. John of Jerusalem}

Those recently appointed to, or promoted in, the Most Venerable Order of the Hospital of St. John of Jerusalem include the following members of the medical profession:

As Knight: Lieutenant-Colonel $\mathrm{H}$. O. Wagg. As Dame: Dr. Margaret F. Gillison. As Commanders (Brothers): Colonel I. M. MacKay, Group Captains I. M. O'Connor, R. W. Povey, Drs. K. W. N. Palmer, E. N. O. Sodeinde, and Mr. R. H. Thorlakson.

\section{People in News}

Professor A. G. E. Pearse, of the Royal Postgraduate Medical School, London, has been elected to membership of the Deutsche Akademie der Naturforscher Leopoldina "for scientific accomplishments in the fields of histochemistry and endocrinology." Professor Pearse has also been elected the first foreign honorary member of the Histochemical Society of Finland" in recognition of his invaluable international contribution to the science of histochemistry."

\section{Winston Churchill Memorial Trust} Travelling Fellowships

The Winston Churchill Memorial Trust awards enable people to travel abroad to widen their knowledge in their own field of activity and that of others in different parts of the world. The distinctive features of the awards are that there are no age limits, and academic or professional qualifications are not needed. However, candidates must be citizens of the United Kingdom. The grants cover all expenses. The subjects in which awards are offered change each year. Included for 1974 are "Consumer Protection in the Food Industry," "Design and Aids for the Handicapped," "Health and Safety in the Ports," "Preparation for Retirement," and "Intensive Care in Hospitals." Applications should be sent on a postcard in September to the Winston Churchill Memorial Trust, 10 Queen Street, Mayfair, London W1X 7PD. An explanatory leaflet and a form to complete which must be returned before 5 November 1973 will be sent to applicants.

\section{Australian Doctors' Fees}

At the end of May the Federal Council of the Australian Medical Association published a list of revised fees for medical services, with increases of around $25 \%$, to be put into effect on 6 August. In a letter sent to Dr. Keith Jones, the president of the A.M.A., on 20 June, the Minister for Social Security said that the Government could not accept the A.M.A.'s proposed fee increases, and continued that he proposed "to establish an independent tribunal to adjudicate on the . . . fee levels .... and the inquiry should be an open public one." The A.M.A. Federal Council called a special meeting to discuss the subject on 29 June, the outcome of which was a recommendation to A.M.A. members to "use, and charge in accordance with, the A.M. List of Medical Services and Fees as from August 6", and a statement from the Council that a public inquiry would be welcomed.

\section{COMING EVENTS}

Institute of Health Service Administrators (East Anglia Region).-Weekend school, 28-30 September, Great Yarmouth. Fee $£ 15$ (nonresidents $£^{8.50)}$. Details from Mr. E. M. D. Goddard, Lowestoft and North Suffolk Hospital Tennyson Road, Lowestoft, Suffolk. (Tel. Lowestoft 5151.)
"Rehabilitation of the Arthritis Patient in the Community."-Symposium, 14 September, Headington, Oxford. Fee $f 1.50$ (including lunch). Details and tickets from the Arthritis and Rheumatism Council, 8 Charing Cross Road, London WC2H OHN. (Tel. 01-240 0871).

Institute of Neurological Sciences, Glasgow.Copies and details of the postgraduate teaching programme, August-December, are obtainable from Dr. David Doyle, Neuropathology Department, Institute of Neurological Sciences, Glasgow S.W.1.

\section{APPOINTMENTS}

Birmingham Regional Hospital BoArd.-Dr. P. J. H. Fletcher (consultant in morbid anatomy/neuro pathology, North Staffordshire group); Dr. W. J. C Parker (consultant physician, geriatrics, Mid- Worcestershire group and the Worcestershire County and South Worcestershire groups); Dr. M. A.'Khan (consultant physician, to develop a special interest in rheumatology, Wolverhampton group). (consultant nephrologist).

MANChester Regional Hospital Boarp.-Dr. M. L Sutton (consultant radiotherapist, Christie Hospital and Holt Radium Institute); Dr. A. King (consultant psychiatrist, Blackpool and Fylde group and Lancaster in geriatric medicine, Rochdale and District group) Dr. A. R. Maude (consultant anaesthetist, Rochdale and District group); Dr. M. Hughes (consultant pathologist morbid anatomy, Wythenshawe and North Cheshire group); Mr. M. R. Heal (consultant urologist, South surgeon, West Manchester and W Wthen (consultant e.n.t. surgeon, West Manchester and W ythenshawe and North orthopaedic surgeon, Wr. B. M. Wroblewski (consultan Wadsworth (consultant haematologist, National Blood Transfusion Service, Manchester)

\section{Corrections}

Comparison of Co-trimoxazole and Chloramphenical in Enteric Fever

In the letter from Dr. A. Hassan and others (14 July, p. 108) the dosage of co-trimoxazole was given as $10 \mathrm{mg} / \mathrm{kg}$ body weight daily. This referred to the trimethoprim component of co-trimoxazole only, the accompanying dosage of sulphamethoxazole being $50 \mathrm{mg} / \mathrm{kg}$.

\section{New Editor of "J.A.M.A."}

Dr. Robert H. Moser (11 August, p. 363) has been in private practice in Hawaii for the past two years, and not five as inadvertently printed.

\section{Notice to Authors}

When original articles and letters for publication are not submitted exclusively to the British Medical fournal this must be stated. Accepted articles may subsequently be selected for publication in the North American monthly edition.

Correspondence on editorial business should be addressed to the Editor, British Medical fournal, B.M.A. House, Tavistock Square, London WC1H 9JR. Telephone: 01-387 4499. Telegrams: Aitiology, London, W.C.1.

Authors wanting reprints of their articles should notify the Publishing Manager, B.M.A. House, Tavistock Square, WC1H 9JR, on receipt of proofs.

\section{(C) British Medical Journal 1973}

All Rights Reserved. No part of this publication may be reproduced, stored in a retrieval system, or transmitted, in any form or by any means, electronic, mechanical, photocopying, recording or otherwise, without the prior permission of the British Medical fournal. 